\title{
Impacts of Video-Recorded Feedback in Public Speaking Classes: An Empirical Study
}

\author{
Do Thi Quy Thu \\ Hue College of Foreign Languages, Hue, Vietnam \\ Dang Thi Cam Tu \\ Hue College of Foreign Languages, Hue, Vietnam
}

\begin{abstract}
This paper presents a rather unexplored teaching technique in classrooms in Vietnam: video-recorded feedback. The objective of this study is two-fold: (1) to investigate the impacts of video-recorded feedback on students' communication competence and communication apprehension in a Public Speaking course of English as a Foreign Language (EFL) students at a university in Vietnam, and (2) to gain insights into students' attitudes towards the application of video-recorded feedback in the public speaking course. Data was collected via video recording of students' presentations, students' reflection forms, questionnaires and in-depth interviews. The findings have revealed positive effects of video-recorded feedback as well as positive attitudes of the students towards this still-new type of feedback. These empirical study results also have implications for the potential application of video-recorded feedback to EFL courses and programs in Vietnam and other similar contexts in Asia or elsewhere.
\end{abstract}

Public speaking plays a vital part in today's life. Patil (2006) stated that "the ability to give a great presentation can be a tremendous career booster, while the inability to do so can keep you on a dead-end path" (p. 1). Due to their importance, oral presentation skills in general and public speaking skills in particular have been greatly emphasized in the current English course syllabuses of many universities. In the context of the university in this research, students in several speaking classes and specialized courses are required to make oral presentations in class and these presentations are also assessed as part of their final results. When students go to work, they need to communicate effectively in various communicative events, using appropriate language and excellent presentation skills. Therefore, it is vital to enhance students' public speaking skills when they are still in university.

Providing effective and constructive feedback in a performance course such as a public speaking course, as indicated by Quigley and Nyquist (1992), is necessary for teachers to 
improve their students' presentation skills. Quigley and Nyquist (1992) emphasized that thoughtful feedback, especially in the public domain, stimulates students to be reflective about their performance and has an important long-term influence on their communication skills. Specifically, feedback serves the following purposes: (a) to help speakers know about the audience's reaction to their speech, (b) to suggest improvements, (c) to encourage speakers to speak again or to enjoy speaking, and (d) to increase speakers' self-understanding (Brook, 1985, as cited in Quigley \& Nyquist, 1992). In teaching public speaking and evaluating speeches, giving meaningful feedback on students' work is always "a commitment in any teachinglearning situation" (Kaur, 2005, para. 1). To obtain the most effectiveness from public speaking courses, with the ever-increasing integration of technology into classes over the last decades, a new type of feedback, i.e., video-recorded feedback, has been widely adopted in these courses, as found in many studies (e.g., Dupagne, Stacks, \& Giroux, 2006; Glenn, 1996; Mallard \& Quintanilla, 2008; Quigley \& Nyquist, 1992).

Video-recorded feedback. Video-recorded feedback, or video feedback, "refers to a structured process whereby students review their recorded communication with the benefit of some guidance and / or evaluation from an instructor or peers" (Quigley \& Nyquist, 1992, p. 325). Video recording, considered "a third eye as a tool for performance enhancement" (Glenn, 1996 , p. 1), proves to be a powerful instructional aid in public speaking courses due to its capacity to preserve students' performances for later analysis and self-reflection. In this sense, and within the scope of the current study, video-recorded feedback is closely defined as selfevaluation feedback.

The positive effects of video-recorded feedback in public speaking courses have been firmly asserted by several researchers (Bankston \& Terlip, 1994; Dupagne et al., 2006; Hinton \& Kramer, 1998; Miles, 1981; Quigley \& Nyquist, 1992). As stated by Quigley and Nyquist (1992) and Lucas (1995, as cited in Glenn, 1996), video technology allows students in public speaking classes to review their performances, thereby helping them know how they look and sound in the eyes and ears of their audience. Moreover, Quigley and Nyquist (1992) added three more benefits video-recorded feedback offers students: getting feedback at the time of their performance, identifying or emphasizing particular skills, and comparing different performances. Miles (1981) revealed that students showcase greater oral communication skills after viewing a video replay of their performances. Dupagne, Stacks, and Giroux (2006) further posited that by viewing their speeches, students can become more aware of weaknesses in their presentation style, such as poor body posturing, excessive gesturing, and frequent use of interrupters.

In reaching the main goals of a public speaking course, many studies have examined the impacts of these courses on students' perceptions of their communication competencies, in which very often students are measured on their communication competence and communication apprehension (e.g., Dupagne et al., 2006; Glenn, 1996; Hinton \& Kramer, 1998).

Communication competence. According to Rubin (1990), communication competence is knowledge about appropriate and effective communication behaviors, development of skills to communicate appropriately and effectively, and motivation to behave appropriately and effectively (as cited in Dupagne et al., 2006).

Ford and Wolvin (1993) developed a course evaluation instrument containing 24 items with different communication competencies across three different contexts: in class, at work, and in social settings, shown in Figure 1 below. 
1. Feeling confident about yourself

2. Feeling comfortable with others' perceptions of you

3. Reasoning with people

4. Using language appropriately

5. Understanding nonverbal messages

6. Communicating in personal relationships

7. Managing conflict in personal relationships

8. Asserting yourself (without becoming aggressive)

9. Listening to others in personal relationships

10. Feeling comfortable communicating in personal relationships

11. Preparing questions and materials for an interview

12. Conducting an interview

13. Feeling comfortable when conducting an interview

14. Completing tasks in a small group situation

15. Interacting with others in a small group situation

16. Listening to others in a small group situation

17. Feeling comfortable communicating in a small group situation

18. Preparing and organizing speeches

19. Presenting speeches in front of an audience

20. Listening to speeches

21. Feeling comfortable when delivering speeches

22. Persuading people

23. Your overall ability speaking to others in different situations

24. Your overall ability listening to others in different situations

Figure 1. Perceived communication competencies. Ford and Wolvin (1993).

Communication apprehension. McCroskey (1977) defined communication apprehension as "an individual's level of fear or anxiety associated with either real or anticipated communication with another person or persons" (p. 78, as cited in Dupagne et al., 2006). Zimbardo (1977, as cited in Dupagne et al., 2006) found in his study that, as to university students, their shyness when speaking in public is a contributing factor to communication apprehension, which is exhibited in up to $73 \%$ of the students. This finding about communication apprehension could be relevant to what is found in EFL students in Vietnam or other Asian contexts, who "have added dimensions of fear, insecurity and anxiety when it involves speaking in front of their peers" (Kaur, 2005, para. 1).

McCroskey (1982, as cited in McCroskey, Beatty, Kearney, \& Plax, 1985) developed the latest version of PRCA-24 (Figure 2) based on an earlier instrument measuring communication apprehension by McCroskey and Richmond (1980). This new instrument involves four communication contexts, including public speaking, speaking in small groups, speaking in meetings, and speaking in dyads. There are six items for each context. With this instrument, students indicate the degree to which each statement applies to them on a 5-point Likert-type scale from 1 (strongly agree) to 5 (strongly disagree). As with McCroskey, Beatty, Kearney, and Plax (1985), because this scale has already been extensively tested for validity and reliability, the standard scoring approach was used for the four subscales. 
Directions: This instrument is composed of 24 statements concerning your feelings about communication with other people. Please indicate in the space provided the degree to which each statement applies to you by marking whether you (1) Strongly Agree, (2) Agree, (3) Are Undecided, (4) Disagree, or (5) Strongly Disagree with each statement. There are no right or wrong answers. Many of the statements are similar to other statements. Do not be concerned about this. Work quickly, just record your first impression.

1. I dislike participating in group discussions.

2. Generally, I am comfortable while participating in a group discussion.

3. I am tense and nervous while participating in group discussions.

4. I like to get involved in group discussions.

5. Engaging in a group discussion with new people makes me tense and nervous.

6. I am calm and relaxed while participating in group discussions.

7. Generally, I am nervous when I have to participate in a meeting.

8. Usually I am calm and relaxed while participating in meetings.

9. I am very calm and relaxed when I am called upon to express an opinion at a meeting.

10. I am afraid to express myself at meetings.

11. Communicating at meetings usually makes me uncomfortable.

12. I am very relaxed when answering questions at a meeting.

13. While participating in a conversation with a new acquaintance, I feel very nervous.

14. I have no fear of speaking up in conversations.

15. Ordinarily I am very tense and nervous in conversations.

16. Ordinarily I am very calm and relaxed in conversations.

17. While conversing with a new acquaintance, I feel very relaxed.

18. I am afraid to speak up in conversations.

19. I have no fear of giving a speech.

20. Certain parts of my body feel very tense and rigid while giving a speech.

21. I feel relaxed while giving a speech.

22. My thoughts become confused and jumbled when I am giving a speech.

23. I face the prospect of giving a speech with confidence.

24. While giving a speech I get so nervous, I forget facts I really know.

\section{SCORING:}

Group $=18-(1)+(2)-(3)+(4)-(5)+(6)$

Meeting $=18-(7)+(8)+(9)-(10)-(11)+(12)$

Dyadic $=18-(13)+(14)-(15)+(16)+(17)-(18)$

Public $=18+(19)-(20)+(21)-(22)+(23)-(24)$

Overall CA $=$ Group + Meeting + Dyadic + Public

Figure 2. Personal Report of Communication Apprehension (PRCA-24). McCroskey (1982, as cited in McCroskey et al, 1985).

The two above-mentioned instruments display their wide use of evaluation in different communication contexts, i.e., in class, at work and in social settings (Ford \& Wolvin, 1993), and in groups, in meetings, in dyadic and public speaking (McCroskey et al., 1985). Research adopting either of these two instruments has shown that taking a basic public speaking course increases students' perceptions of their communication competencies in such different contexts 
(Ericson \& Gardner, 1992; Kramer \& Hinton, 1996; Rubin, Rubin, \& Jordan, 1997). However, limited research suggests that students' communication competencies could be enhanced in public speaking courses with the application of technology such as video recording. What is more, whilst much literature has grown around the public speaking arena, studies on video recording and video-recorded feedback are still largely neglected in the Vietnamese pedagogical setting (Do \& Dang, 2012; Duong, 2003). Video-recorded feedback, although already addressed as a convenient way to enhance students' public speaking skills for the long term (e.g., Bankston \& Terlip, 1994; Bourhis \& Allen, 1998; Bunz, 2002; Hirschfeld, 1968), remains an unproven technique, specifically in Vietnam pedagogical public speaking context. Do and Dang's (2012) review article of published studies of video-recorded feedback in public speaking has suggested that this kind of feedback can be potentially employed as an effective pedagogical tool to improve the overall performance of students in public speaking courses. To increase teaching success in public speaking courses, this research was implemented to scrutinize the effects of video feedback on students' communication skills in public speaking. It specifically uses Ford and Wolvin's (1993) course evaluation instrument of communication competencies and McCroskey's (1982, as cited in McCroskey et al., 1985) Report of Communication Apprehension to find the results for the study. Within the recent research's focus of investigating impacts of video-recorded feedback in public speaking classes, the application of these two instruments has been modified and restricted to a scope relating to public speaking only.

This study, with its all useful information and implications, is anticipated to arouse EFL teachers' consciousness of the importance of applying video-recorded feedback in public speaking classes. Also, the study hopefully provides a good grasp on the effects of video feedback on students' communication skills and communication apprehension. Lastly, students' attitude towards the application of video feedback in real public speaking courses is probed, which offers teachers a chance to reflect on the feasibility of applying this technique in their teaching environment. In pursuit of the aforesaid goals, this research seeks to address the following questions:

1. How does video-recorded feedback affect the students' communication competence and communication apprehension in public speaking courses?

2. What are the students' attitudes towards the application of video-recorded feedback in public speaking classes?

\section{Participants}

\section{Research Methodology}

The participants were 50 third-year EFL students in a public speaking course at a university of foreign languages in Vietnam. At this level, the students were categorized as upperintermediate or advanced in terms of their English language speaking proficiency based on the required Common European Framework of Reference tests they took at the end of their second year. The instructor is also the researcher.

\section{Course Description}

The public speaking course is also called Speaking 5. Students register for this course after finishing four prerequisite courses, Speaking 1 to Speaking 4. The course lasts for 30 periods and has one two-period meeting (50 minutes per period) per week. The first 10 periods are for theory, with one mid-term test on theory, and the last 20 periods are for practice. In this study, each student was required to do two 5-7 minute presentations: one related to theory in the first 
10 weeks and the other on an optional topic. The interval between the two presentations was five to six weeks.

\section{Instruments}

Video recording. All presentations were video recorded with the instructor's camera. Recording of each student contained his / her five to seven-minute presentation and two minutes of questions and answers. Each recording was burned into a DVD and sent to each student one to two days afterwards.

Reflection forms. Each student was advised to view his or her video-recorded presentation and fill in the questionnaires and reflection form. The two reflection forms (see Appendices A and B) were delivered by the course instructor and submitted to the instructor one week after each of the two presentations. The reflection forms, with some intentionally different question items in the first and the second forms, aimed at collecting data regarding the students' attitudes towards this type of feedback as well as the strengths and weaknesses that they perceived after watching their presentations. All the students' statements in the reflection forms as well as the forms themselves were in English. All fifty and forty-seven out of the 50 students handed in their first and second reflection forms respectively. Data for the study was consequently taken from the forty-seven students who submitted their two reflections.

Questionnaires. Questionnaires were designed to deliver before and after the course (pre-test and post-test), aiming to investigate the impacts of video-recorded feedback on the students' communication competence and communication apprehension. Two scales were employed in this research: one measuring communication competencies and one measuring communication apprehension.

Communication competencies. Communication competency items were modified from the course evaluation instrument of Ford and Wolvin (1993) (Figure 1). Aiming at evaluating students' communication competencies in public speaking classes, the researcher selected 10 items relevant to public speaking classes for this research. Student-respondents described their abilities for each item with a 7-point Likert-type scale ranging from $O$ (none) to 7 (great).

Communication apprehension. Communication apprehension items were modified from the instrument PRCA-24 of McCroskey et al. (1985; Figure 2). With this instrument, the students indicated the degree to which each statement applied to them on a 5-point Likert-type scale from 1 (strongly agree) to 5 (strongly disagree). The researcher selected six items relevant to public speaking classes for this research.

In-depth interviews. Five volunteer students from the participants were interviewed about their attitude towards video-recorded feedback. These interviews were conducted in the native language of the participants and the researcher, i.e., Vietnamese, in order to avoid any potential language barrier to the participants' expressions.

\section{Data Analysis}

The data collected from the reflection forms, questionnaires, and interviews were categorized, coded, and analyzed by qualitative methods and quantitative methods using the Statistics Package for Social Studies Version 19.0. The students' reflections and expressions in the reflection forms and interviews were translated into English by the researcher for analysis. The names of the students appearing in this research are pseudonyms. 


\section{Findings and Discussion}

\section{Impacts of Video-Recorded Feedback on Students' Communication Competencies}

The impacts of video-recorded feedback are evaluated based on analyzing data on changes in students' perceptions before and after the course. The researcher chose 10 items (out of 24) in the instrument of Ford and Wolvin (1993) and divided them into 3 categories: confidence, presentation, and interpersonal communication. The findings for the pre-test and post-test are shown in Table 1 and Table 2.

Table 1

Changes in Perceived Communication Competencies (Mean Scores)

\begin{tabular}{|c|c|c|c|c|}
\hline & & & Pre-test & Post-test \\
\hline \multirow{4}{*}{ Confidence } & 1 & Feeling confident about yourself & 3.06 & 4.87 \\
\hline & 2 & Asserting yourself without becoming aggressive & 3.49 & 4.94 \\
\hline & 3 & Feeling comfortable when delivering speeches & 3.74 & 4.83 \\
\hline & 4 & Persuading people & 4.11 & 5.26 \\
\hline \multirow{2}{*}{ Presentation } & 5 & Preparing and organizing speeches & 4.36 & 5.55 \\
\hline & 6 & Presenting speeches in front of an audience & 4.30 & 5.23 \\
\hline \multirow{4}{*}{$\begin{array}{l}\text { Interpersonal } \\
\text { communication }\end{array}$} & 7 & Understanding nonverbal messages & 3.74 & 5.15 \\
\hline & 8 & $\begin{array}{l}\text { Feeling comfortable with others' perceptions of } \\
\text { you }\end{array}$ & 4.72 & 5.34 \\
\hline & 9 & Reasoning with people & 4.06 & 5.40 \\
\hline & 10 & Using language appropriately & 4.02 & 5.57 \\
\hline
\end{tabular}

Note. $n=47$

The overall mean scores of the above three main categories (i.e., confidence, presentation, and intercultural communication) are displayed in Table 2.

Table 2

Changes in Perceived Communication Competencies (Overall Mean Scores)

\begin{tabular}{|l|c|c|c|}
\hline \multirow{2}{*}{} & \multicolumn{2}{|c|}{ Mean $(M)$} & \multirow{2}{*}{$\begin{array}{c}\text { Pre-to-post } \\
\text { change }\end{array}$} \\
\cline { 2 - 3 } & Pre-test & Post-test & \\
\hline Confidence & 3.60 & 4.98 & $1.38^{\star \star}$ \\
\hline Presentation & 4.33 & 5.39 & $1.06^{\star \star}$ \\
\hline Interpersonal communication & 4.14 & 5.37 & $1.23^{\star *}$ \\
\hline
\end{tabular}

Note. $n=47 ;{ }^{* *} p<.001$

A pair sample t-test was also conducted to identify the significance of these changes and the findings showed that the $p$ value of these changes was smaller than .001 , proving the reliability of the changes.

As can be seen from Tables 1 and 2, the overall mean scores of all three main communication competencies increased from pre-test to post-test. These findings suggest a strong relationship between video-recorded feedback and improvements. This result could correlate with that of 
Hinton and Kramer (1998), who found that over $75 \%$ of the respondents indicated improvements in communication competencies.

After viewing their presentations, the students realized their weakness in confidence and promised to improve in the next set of presentations. For example, one student stated:

I didn't speak loudly enough. I forgot some ideas so I spoke softly. Although I didn't read information in the slideshow, I didn't have much eye contact with the audience as I was trembling.

On the reflection forms, some students admitted that they recognized some pronunciation mistakes they had made but had not paid attention to before. Many students wrote about their presentation pace; some were too quick and some were too slow. Several students mentioned that they should be more careful about preparation and rehearsals next time. More than half of the students reflected on their limitations in eye contact and facial expressions. Typically, one wrote:

I think my presentation would have been more interesting if I had smiled to the audience more and shown a more friendly attitude, instead of my nervous face.

As for another student, the reflection was:

I have to find wiser ways to respond to the audience's questions, especially when I don't know the answer immediately.

Generally, students' improvements in communication competence can be perceived to some extent through the findings above.

\section{Impacts of Video-Recorded Feedback on Students' Communication Apprehension}

As shown in Table 3, there was a big difference in the students' apprehension before and after viewing their recorded presentations. This difference, to some extent, reflected positive impacts of this type of feedback on students' communication apprehension. 


\section{Table 3}

\section{Changes in Communication Apprehension}

\begin{tabular}{|c|c|c|c|c|c|c|c|c|c|c|c|}
\hline & & \multicolumn{2}{|c|}{$\begin{array}{c}\text { Totally agree } \\
(\%)\end{array}$} & \multicolumn{2}{|c|}{$\begin{array}{c}\text { Agree } \\
(\%)\end{array}$} & \multicolumn{2}{|c|}{$\begin{array}{c}\text { Not sure } \\
(\%)\end{array}$} & \multicolumn{2}{|c|}{$\begin{array}{c}\text { Disagree } \\
(\%)\end{array}$} & \multicolumn{2}{|c|}{$\begin{array}{c}\text { Totally } \\
\text { disagree } \\
(\%)\end{array}$} \\
\hline & & Pre & Post & Pre & Post & Pre & Post & Pre & Post & Pre & Post \\
\hline 1 & $\begin{array}{l}\text { I have no fear } \\
\text { of giving a } \\
\text { speech }\end{array}$ & 0.00 & 21.28 & 4.26 & 38.30 & 2.12 & 4.26 & 29.79 & 21.28 & 63.83 & 14.89 \\
\hline 2 & $\begin{array}{l}\text { Certain parts } \\
\text { of my body } \\
\text { feel very tense } \\
\text { and rigid while } \\
\text { giving a } \\
\text { speech }\end{array}$ & 61.70 & 21.28 & 25.53 & 21.28 & 0.00 & 2.13 & 12.77 & 34.04 & 0.00 & 21.28 \\
\hline 3 & $\begin{array}{l}\text { I feel relaxed } \\
\text { while giving a } \\
\text { speech }\end{array}$ & 0.00 & 10.64 & 0.00 & 21.28 & 6.38 & 0.00 & 25.53 & 25.53 & 68.09 & 42.55 \\
\hline 4 & $\begin{array}{l}\text { My thoughts } \\
\text { become } \\
\text { confused and } \\
\text { jumbled when } \\
\text { giving the } \\
\text { speech }\end{array}$ & 42.55 & 25.53 & 40.43 & 31.91 & 0.00 & 0.00 & 10.64 & 31.91 & 6.38 & 10.64 \\
\hline 5 & $\begin{array}{l}\text { I face the } \\
\text { prospect of } \\
\text { giving a } \\
\text { speech with } \\
\text { confidence }\end{array}$ & 0.00 & 14.89 & 10.64 & 14.89 & 0.00 & 4.26 & 55.32 & 53.19 & 34.04 & 12.77 \\
\hline 6 & $\begin{array}{l}\text { While giving a } \\
\text { speech, I get } \\
\text { so nervous, I } \\
\text { forget facts I } \\
\text { really know }\end{array}$ & 55.32 & 29.79 & 25.53 & 23.40 & 8.51 & 2.13 & 10.64 & 29.79 & 0.00 & 14.89 \\
\hline
\end{tabular}

Note. For the pre-test and post-test, $n=47$

Specifically, before the study, only a small percentage of students $(4.26 \%)$ thought that they didn't feel afraid of presenting while most students (93.62\%) did. After video-recorded feedback being applied in class, only $36.17 \%$ reflected that they still felt afraid.

For the third item, none of the students felt relaxed giving a speech at the beginning of the course, but this figure increased to $31.92 \%$ afterwards. Also, for the fifth item, only $10.64 \%$ felt confident before the study, but this number nearly tripled after the study.

Regarding thinking ability, $82.98 \%$ of students chose "totally agree" or "agree" for "My thoughts become confused and jumbled when giving a speech" in the pre-test; this rate decreased to $57.44 \%$ in the post-test. In addition, $87.23 \%$ agreed that some parts of their bodies became tense and rigid during their speech, but this rate fell by over half in the post-test.

Many students emphasized their apprehension in their reflections. Bich, a student in the class, wrote: 
When I stood in front of many people, my heart beat fast; my face sometimes became flushed. I couldn't control myself and I began to forget all my presentation content.

Thanks to video-recorded feedback, this student became aware of her weaknesses and prepared and rehearsed more for the next presentation. In the second presentation, Bich tried holding a pencil in her hands and used more gestures; accordingly, she did much better.

Overall, the findings in this study are compatible with those of Dupagne et al. (2006), in which students who experienced video-recorded feedback were less frightened of presenting than those who did not have the same experience.

\section{Students' Comments on Aspects of Video-Recorded Feedback}

The findings revealing students' attitudes towards video-recorded feedback were collected from students' reflection forms and in-depth interviews, which display both positive and negative attitudes.

Positive aspects. All student-participants (50 out of 50) shared the same opinion that videorecorded feedback was a useful technique as because of it, they recognized the limitations in their performance. One student noted:

I can see what and how I acted during my performance. This technique helps us see our strengths and weaknesses as on viewing, we ourselves become audience. (Ly)

The application of video-recorded feedback encouraged students to make more well-prepared presentations.

The recording reminded us to try our best in order to have a few-of-mistake performance. (Ngoan)

Some student-participants pointed out that this modern teaching aid, together with the new teaching technique, inspired them to learn and helped boost their confidence in long-term presentation skills development.

The presence of a camera in my public speaking class makes us curious, happy and eager. I think that is because we are experiencing something new that we have never had before. (Hung)

For the very first time, I was completely surprised by a 'big' camera firmly set in the middle of the room, recording our presentations. (Nam)

I like the camera because I see it as a tool of modern teaching and learning with which I should be acquainted. (Lan)

Thanks to the camera, this presentation becomes an unforgettable memory of my college life. (Hoa)

This technology-bound method is a professional learning and teaching method. (Huy) 
Negative aspects. Besides the above mentioned benefits, the negative sides of video-recorded feedback should also be taken into due consideration. The application of video-recorded feedback complicated students' learning process, as what stated by the following two students:

I hate the camera because it is too complicated to me and it is time-consuming. (Loan)

The sound quality of our recorded video is poor. And we lack computers and equipment to watch our video again. (Hoa)

The camera was also a great distracter for students. Although the camera was used to help students increase their confidence in the long-term, it turned out to be a source of fear and pressure for many in the first few days.

I feel uncomfortable with the camera. When presenting, I paid much attention to it and sometimes I forgot my scripts. (Nguyen)

I felt a bit nervous and trembling when I saw a camera facing me. (Nga)

I know that I was not natural in front of the camera. (Hoa)

\section{Conclusion and Implications}

From the findings, it can be concluded that video-recorded feedback created some improvements in students' communication competence and simultaneously helped reduce students' communication apprehension to some extent. Although students showed both positive and negative attitudes towards video-recorded feedback, all admitted that this feedback had a great impact in helping them realize their mistakes. Instructors of public speaking courses therefore should recognize the significance of video-recorded feedback and widely apply this technique in speaking and public speaking classes. So as to achieve the most benefit from this application, public speaking course instructors are also encouraged to learn more about advanced technology and facilitate the learning process of video-recorded feedback for students. In addition, students should take advantage of evaluation via video-recorded feedback to facilitate their own self-directed learning and be aware of the significance of selfreflecting in their progress.

A limitation of this study lies in the research design. The lack of a control group caused us not to know whether students enrolled in other courses without the application of video-recorded feedback can receive the same benefits as students in the course with video-recorded feedback.

Regardless of this limitation, this research does provide some additional insights into the effectiveness of applying video-recorded feedback in public speaking courses that can be beneficial to the enhancement of students' communication skills. The study suggests the need for further assessment of the effectiveness of technology integration in communication courses. Further research might replicate this study but with the inclusion of a control group, or examine the relationship between student self-assessment and instructor assessment of students' videorecorded presentations. 


\section{Author Note}

Do Thi Quy Thu, Department of English, Hue College of Foreign Languages, Hue, Vietnam; Dang Thi Cam Tu, Department of English, Hue College of Foreign Languages, Hue, Vietnam.

Correspondence concerning this article should be addressed to Do Thi Quy Thu, Department of English, Hue College of Foreign Languages, 57 Nguyen Khoa Chiem, Hue City, Vietnam. Email: belovedautumn@gmail.com 


\section{References}

Bankston, R. G., \& Terlip, L. A. (1994, November). The effects of videotaping on student performances in the basic communication course. Paper presented at the annual meeting of the Speech Communication Association, New Orleans, LA. http://files.eric.ed.gov/fulltext/ED378604.pdf

Bourhis, J., \& Allen, M. (1998). The role of videotaped feedback in the instruction of public speaking: A quantitative synthesis of published empirical research. Communication Research Reports, 15 (3), 256-261. http://dx.doi.org/10.1080/08824099809362121

Bunz, U. (2002). An evaluation of technology use in the basic public speaking classroom. In: L. Hugenberg \& B. Hugenberg, Teaching ideas for the basic communication course, Volume 6 (pp. 3-10). Dubuque, lowa: Kendall/Hunt. bunz.comm.fsu.edu/handbook_tech_public.pdf

Do, T. Q. T., \& Dang, T. C. T. (2012). Videotaped feedback in public speaking courses: Potential application to Vietnamese pedagogical setting. Journal of Science, Hue University, 7011), 237-246. http://hueuni.edu.vn/portal/data/doc/tapchi/22.pdf

Duong, T. H. O. (2003). Teaching and learning oral presentation for learners of English in universities in Vietnam and New Zealand: A comparative study (Unpublished dissertation). Victoria University of Wellington, New Zealand.

Dupagne, M., Stacks, D. W., \& Giroux, V. M. (2006). Effects of video streaming technology on public speaking students' communication apprehension and competence. Journal of Educational Technology Systems, 35(4), 479-490. http://dx.doi.org/10.2190/59474W72-303L-Q578

Ericson, P. M., \& Gardner, J. W. (1992). Two longitudinal studies of communication apprehension and its effects on college students' success. Communication Quarterly, 4O(2), 127-137. http://dx.doi.org/10.1080/01463379209369828

Ford, W. S. Z., \& Wolvin, A. D. (1993). The differential impact of a basic communication course on perceived communication competences in class, work, and social contexts. Communication Education, 42(3), 215-223. http://dx.doi.org/10.1080/03634529309378929

Glenn, R. J. (1996, September). Using video to enhance content and delivery skills in the basic oral communication course: Summarizing the uses and benefits. Paper presented at the Fall Conference of the Kentucky Communication Association, Lake Cumberland, KY.

Hinton, J. S., \& Kramer, M. W. (1998). The impact of self-directed videotape feedback on students' self-reported levels of communication competence and apprehension. Communication Education, 472), 151-161. http://dx.doi.org/10.1080/03634529809379119

Hirschfeld, A. G. (1968). Videotape recordings for self-analysis in the speech classroom. Communication Education, 17(2), 116-118. http://dx.doi.org/10.1080/03634526809377660

Kaur, S. (2005). Suggestions for teaching public speaking and evaluating speeches. The Internet TESL Journal, 11(7). Retrieved from http://iteslj.org/Techniques/KaurPublicSpeaking.html

Kramer, M. W., \& Hinton, J. S. (1996). The differential impact of a basic public speaking course on perceived communication competencies in class, work, and social contexts. In C. Newburger (Ed.), Basic communication course annual(Vol. 8, pp. 1-25). Boston, MA: Academic Press.

Mallard, J., \& Quintanilla, K. (2008). Does videotaped feedback for speeches impact student learning? Student self-assessment of public speaking. Paper presented at the annual meeting of the NCA 93rd Annual Convention. Retrieved from http://www.allacademic.com/meta/p195338_index.html 
McCroskey, J. C., \& Richmond, V. P. (1980). The quiet ones: Communication apprehension and shyness. Dubuque, IA: Gorsuch-Scarisbrick.

McCroskey, J. C., Beatty, M. J., Kearney, P., \& Plax, T. G. (1985). The content validity of the PRCA-24 as a measure of communication apprehension across communication contexts. Communication Quarterly, 33(3), 165-173. http://dx.doi.org/10.1080/01463378509369595

Miles, P. L. (1981). Student video self-critiques. Communication Education, 30(3), 280-283. Retrieved from http://dx.doi.org/10.1080/03634528109378481

Patil, Z. N. (2006). Oral presentation skills for prospective business executives. Asian EFL Journal, 1.

Quigley, B. L., \& Nyquist, J. D. (1992). Using video technology to provide feedback to students in performance courses. Communication Education, 41(3), 324-334. http://dx.doi.org/10.1080/03634529209378892

Rubin, R. B., Rubin, A. M., \& Jordan, F. F. (1997). Effects of instruction on communication apprehension and communication competence. Communication Education, 46(2), 104114. http://dx.doi.org/10.1080/03634529709379080 


\section{Appendix A \\ Student Reflection Form 1 (After Presentation 1)}

Name of presenter:

Topic:

Instructions: Each category should be rated on a scale of 1-5 (circle the relevant number of your rating).

\begin{tabular}{|c|c|c|c|c|}
\hline 1 & 2 & 3 & 4 & 5 \\
\hline Poor & Fair & Good & Very good & Excellent \\
\hline
\end{tabular}

\section{OVERALL EVALUATION}

\begin{tabular}{|l|l|l|l|l|l|}
\hline Speech met the time limit & 1 & 2 & 3 & 4 & 5 \\
\hline Speech showed evidence of research & 1 & 2 & 3 & 4 & 5 \\
\hline Established a need for audience to listen & 1 & 2 & 3 & 4 & 5 \\
\hline
\end{tabular}

Total:

What do you think you could have done to improve your presentation?

\section{ORGANIZATION and CONTENT}

\begin{tabular}{|l|l|l|l|l|l|}
\hline Overall organization of the speech was clear and easy to follow & 1 & 2 & 3 & 4 & 5 \\
\hline Organizational pattern was appropriate for topic and type of speech & 1 & 2 & 3 & 4 & 5 \\
\hline Transitions provided necessary links between ideas & 1 & 2 & 3 & 4 & 5 \\
\hline Interesting and informative content & 1 & 2 & 3 & 4 & 5 \\
\hline Effective selection of key points & 1 & 2 & 3 & 4 & 5 \\
\hline
\end{tabular}

Total:

What do you think you could have done to improve your presentation?

\section{DELIVERY TECHNIQUES}

\begin{tabular}{|l|l|l|l|l|l|}
\hline Lively and enthusiastic manner & 1 & 2 & 3 & 4 & 5 \\
\hline Stance and posture was appropriate & 1 & 2 & 3 & 4 & 5 \\
\hline Eye contact was appropriate & 1 & 2 & 3 & 4 & 5 \\
\hline Gestures added emphasis and description & 1 & 2 & 3 & 4 & 5 \\
\hline Communicated naturally (did not read) & 1 & 2 & 3 & 4 & 5 \\
\hline Clear and fluent delivery & 1 & 2 & 3 & 4 & 5 \\
\hline
\end{tabular}

Total:

What do you think you could have done to improve your presentation? 


\section{WORD USAGE / LANGUAGE}

\begin{tabular}{|l|l|l|l|l|l|}
\hline Appropriate use of language / words & 1 & 2 & 3 & 4 & 5 \\
\hline Appropriate use of grammar & 1 & 2 & 3 & 4 & 5 \\
\hline Correct pronunciation & 1 & 2 & 3 & 4 & 5 \\
\hline
\end{tabular}

Total:

What do you think you could have done to improve your presentation?

\section{USE OF AIDS / SUPPORTING MATERIALS}

\begin{tabular}{|l|l|l|l|l|l|}
\hline Speech utilized appropriate supporting materials & 1 & 2 & 3 & 4 & 5 \\
\hline Speech utilized a variety of supporting materials & 1 & 2 & 3 & 4 & 5 \\
\hline Supporting materials were clear and easy to see & 1 & 2 & 3 & 4 & 5 \\
\hline
\end{tabular}

Total:

What do you think you could have done to improve your presentation?

TOTAL SCORE: $/ 100$ points

\section{OTHER SELF-REFLECTION:}

\begin{tabular}{|l|l|}
\hline $\begin{array}{l}\text { What can be } \\
\text { your } \\
\text { strengths? }\end{array}$ & \\
\hline $\begin{array}{l}\text { What can be } \\
\text { your } \\
\text { weaknesses? }\end{array}$ & \\
\hline
\end{tabular}

In your next presentation, what do you think you should do to improve your presentation? 


\section{Appendix B \\ Student's Reflection Form 2 (After Presentation 2)}

Name of presenter:

Topic:

Instructions: Each category should be rated on a scale of 1-5 (circle the relevant number of your rating).

\begin{tabular}{|c|c|c|c|c|}
\hline 1 & 2 & 3 & 4 & 5 \\
\hline Poor & Fair & Good & Very good & Excellent \\
\hline
\end{tabular}

\section{OVERALL EVALUATION}

Speech met the time limit

Speech showed evidence of research

Established a need for audience to listen

\begin{tabular}{|l|l|l|l|l|}
1 & 2 & 3 & 4 & 5 \\
\hline 1 & 2 & 3 & 4 & 5 \\
\hline 1 & 2 & 3 & 4 & 5 \\
\hline
\end{tabular}

Total:

In this presentation, what do you think you did better / worse than in your first presentation?

\section{ORGANIZATION and CONTENT}

\begin{tabular}{|l|l|l|l|l|l|}
\hline Overall organization of the speech was clear and easy to follow & 1 & 2 & 3 & 4 & 5 \\
\hline Organizational pattern was appropriate for topic and type of speech & 1 & 2 & 3 & 4 & 5 \\
\hline Transitions provided necessary links between ideas & 1 & 2 & 3 & 4 & 5 \\
\hline Interesting and informative content & 1 & 2 & 3 & 4 & 5 \\
\hline Effective selection of key points & 1 & 2 & 3 & 4 & 5 \\
\hline
\end{tabular}

Total:

In this presentation, what do you think you did better/worse than in your first presentation?

III. DELIVERY TECHNIQUES

\begin{tabular}{|l|l|l|l|l|l|}
\hline Lively and enthusiastic manner & 1 & 2 & 3 & 4 & 5 \\
\hline Stance and posture was appropriate & 1 & 2 & 3 & 4 & 5 \\
\hline Eye contact was appropriate & 1 & 2 & 3 & 4 & 5 \\
\hline Gestures added emphasis and description & 1 & 2 & 3 & 4 & 5 \\
\hline Communicated naturally (did not read) & 1 & 2 & 3 & 4 & 5 \\
\hline Clear and fluent delivery & 1 & 2 & 3 & 4 & 5 \\
\hline
\end{tabular}

Total:

In this presentation, what do you think you did better / worse than in your first presentation? 


\section{WORD USAGE / LANGUAGE}

\begin{tabular}{|l|l|l|l|l|l|}
\hline Appropriate use of language / words & 1 & 2 & 3 & 4 & 5 \\
\hline Appropriate use of grammar & 1 & 2 & 3 & 4 & 5 \\
\hline Correct pronunciation & 1 & 2 & 3 & 4 & 5 \\
\hline
\end{tabular}

Total:

In this presentation, what do you think you did better / worse than in your first presentation?

\section{USE OF AIDS / SUPPORTING MATERIALS}

\begin{tabular}{|l|l|l|l|l|l|}
\hline Speech utilized appropriate supporting materials & 1 & 2 & 3 & 4 & 5 \\
\hline Speech utilized a variety of supporting materials & 1 & 2 & 3 & 4 & 5 \\
\hline Supporting materials were clear and easy to see & 1 & 2 & 3 & 4 & 5 \\
\hline
\end{tabular}

Total:

In this presentation, what do you think you did better / worse than in your first presentation?

TOTAL SCORE: 100 points

\section{OTHER SELF-REFLECTION:}

1. What do you think you have learnt and improved after your two presentations?

2. What do you think about the application of video-recorded feedback to this Public Speaking course? Any suggestions for the improvement of the course? 